AL-MASHRAFIYAH: Jurnal Ekonomi, Keuangan, dan Perbankan Syariah ISSN (p): 2597-4904 ISSN (e) : 2620-5661

Volume 3, Nomor 1, April (2019), h. 1-14

https://doi.org/10.24252/al-mashrafiyah.v3i1.7518

\title{
METODE KUADRAT TERKECIL UNTUK MERAMALKAN TINGKAT LIKUIDITAS PADA BMT KAPUAS MANDIRI SEJAHTERA DI KOTA PONTIANAK
}

\author{
Muhammad Syaifullah $^{1}$, Fachrurazi $^{2}$, Muhammad Khairul Anwari $^{3}$, Dian Anggraini ${ }^{4}$ \\ Pascasarjana IAIN Pontianak ${ }^{1}$ \\ Fakultas Ekonomi dan Bisnis Islam (FEBI) IAIN Pontianak ${ }^{2,3,4}$ \\ muhammadsyaifullah@iainptk.ac.id ${ }^{1}$, \\ ferryfachrurazi@iainptk.ac.id ${ }^{2}$ akhkhair@gmail.com³ ${ }^{3}$, diananggraini20129637@yahoo.co.id ${ }^{4}$
}

\begin{tabular}{ll}
\hline Keywords: & \multicolumn{1}{c}{ ABSTRACT } \\
Cash Ratio, & The aimed of this research is due to the existence of accounting information related \\
Financing To & to liquidity problem in Baitul Maal wa Tamwil/The house of Business and Social \\
Deposit Ratio, & (BMT) "Kapuas Mandiri Sejabtera" by determining the liquidity ratios and \\
Liquidity Ratio & liquidity analysis through the least square trend method analysis. Therefore, we \\
& employ the secondary data sources in the form of financial statements. The result is \\
& that the 2013 Cash Ratio is less liquid, 2014 (liquid), 2015 (illiquid), 2016 \\
& (quite liquid), and 2017 is liquid respectively. Financing to Deposit Ratio (FDR) \\
& ratio in 2013 and 2017 (liquid), 2014 and 2016 (quite liquid), and ultimately in \\
& 2015 (less liquid). Next, The results of the least square quadrant method analysis, \\
& namely the cash ratio from 2013-2017 has depicted that BMT's cash ability to \\
& generate income fluctuated with a downward trend. As for FDR ratio from 2013- \\
& 2017, the ability of financing to generate income has fluctuated whereby the trend \\
& bas experienced a declining from year to year.
\end{tabular}

Kata Kunci:

Rasio Kas, Rasio

Pembiayaan, Rasio

Likuiditas

\section{ABSTRAK}

Adanya informasi akuntansi terkait likuiditas bermasalah di Baitul Maal wa Tamwil (BMT) Kapuas Mandiri Sejahtera. Artikel ini mengulas tingkat rasio likuiditas dan analisis rasio likuiditas. Sumber data sekunder berupa laporan keuangan. Pengumpulan data dengan teknik dokumentasi. Analisis data dengan analisis likuiditas dan trend metode kuadrat terkecil. Hasil yang temukan bahwa cash ratio tahun 2013 (kurang likuid), tahun 2015 (tidak likuid), tahun 2014 (likuid), tahun 2016 (cukup likuid) dan tahun 2017 (likuid). Rasio FDR tahun 2013 dan 2017 (likuid), tahun 2014 dan 2016 (cukup likuid), tahun 2015 (kurang likuid). Hasil analisis Metode Kuadrat Terkecil yaitu cash ratio dari tahun 2013-2017 kemampuan kas di BMT dalam menghasilkan pendapatan mengalami fluktuasi. Dengan trend metode kuadrat terkecil, kas memiliki kecenderungan menurun dari tahun 2013-2017. Rasio FDR dari tahun 2013-2017, kemampuan pembiayaan dalam menghasilkan pendapatan mengalami fluktuasi. Analisis trend metode kuadrat terkecil menunjukkan bahwa pembiayaan memiliki kecenderungan menurun dari tahun 2013-2017. 
Muhammad Syaifullah, et al. Metode Kuadrat Terkecil Untuk Meramalkan...

\section{PENDAHULUAN}

Perkembangan ekonomi di Indonesia saat ini lebih pesat dibandingkan dengan beberapa tahun lalu. Hal ini dapat dibuktikan dengan semakin meningkatnya jumlah lembaga keuangan yang ada. Dalam jangka panjang, keberadaan lembaga keuangan akan memberi manfaat berupa pengembangan ekonomi (Abror, et al., 2005). Dapat kita ketahui lembaga keuangan dikenal ada dua macam, yaitu lembaga keuangan bank dan lembaga keuangan non bank. Adapun peranan utama dari kedua lembaga ini relatif sama, yaitu sebagai perantara keuangan (financial intermediation) antara surplus unit (ultimate lenders) dengan definisi unit (ultimate borrowers) (Mulyono, 2015). Lembaga keuangan bank adalah suatu lembaga keuangan yang memberikan jasa-jasa keuangan dan menarik dana dari masyarakat secara langsung. Misalnya Bank Konvensional dan Bank Syariah. Lembaga keuangan bukan bank ialah semua badan yang melakukan kegiatan dibidang keuangan, yang secara langsung ataupun tidak langsung menghimpun dana terutama dengan jalan mengeluarkan kertas berharga dan menyalurkan ke dalam masyarakat, terutama guna membiayai investasi perusahaan-perusahaan (Abdullah, et al., 2014).

Salah satu lembaga keuangan bukan bank ialah Baitul Mal Wa Tamwil (BMT) yang berperan cukup besar dalam membangun iklim usaha yang sehat di Indonesia. Bahkan ketika terjadi krisis ekonomi dan moneter, BMT seiring melakukan observasi dan supervisi ke berbagai lapisan masyarakat untuk menelaah bagi terbukanya peluang kemitraan usaha. Hal tersebut ditujukan untuk membangkitkan kembali sektor riil yang banyak digeluti oleh kalangan usaha kecil dan menengah serta untuk memperbaiki kesejahteraan ekonomi masyarakat secara keseluruhan (Suhendi, 2004). Walaupun BMT merupakan lembaga keuangan non bank namun dalam memanajemen keuangan juga harus terarah. Manajemen keuangan merupakan kegiatan pembelanjaan perusahaan yang hanya berorientasi pada aktivitas penggunaan dana, sampai saat ini manajemen keuangan berkembang tidak hanya kegiatan penggunaan dana tetapi juga kegiatan mengelola dana agar aktivitas yang dilakukan dapat efisien dan menguntungkan (Sulindawati, et al., 2017).

Salah satunya dengan mengelola laporan keuangan yang baik dan benar. Salah satu sumber informasi penting yang digunakan manajemen dalam pengambilan keputusan tersebut, terutama keputusan keuangan adalah laporan keuangan. Laporan keuangan juga menunjukkan apa yang telah dilakukan manajemen atau mempertanggung jawaban manajemen atas sumber daya yang dipercayakan kepadanya (Najmudin, 2011). Analisis rasio keuangan dirancang untuk membantu mengevaluasi laporan keuangan. Dalam penghitungan analisis rasio digunakan data yang terdapat dalam neraca dan laporan laba rugi. Analisis rasio keunagan ini dibagi dalam lima kategori, yaitu rasio likuiditas, rasio aktivitas, rasio hutang, rasio kemampuan dan rasio nilai pasar (Astuti, D, 2004). Salah satu ukuran kinerja keuangan adalah likuiditas. Konsep likuiditas dapat diartikan sebagai kemampuan perusahaan dalam melunasi sejumlah utang jangka pendek, umumnya kurang dari satu tahun. Dimensi konsep likuiditas mencakup current rasio, quick rasio, cash rasio, dan net working capital to total asset rasio. Dimensi konsep likuiditas tersebut mencerminkan ukuran-ukuran kinerja manajemen ditinjau dari sejauh mana manajemen mampu mengelola modal kerja yang didanai dari utang lancar dan saldo kas perusahaan (Harmono, 2009).

Setiap BMT akan mempunyai perhatian yang besar terhadap keuangan dari bmt tersebut. Keberhasilan maupun kegagalan dalam usahanya hampir sebagian dipengaruhi ataupun ditentukan oleh pengelolaan keuangan bmt. Pada kenyataannya masih terdapat permasalahan terkait dengan likuiditas di lembaga keuangan mikro syariah yang termasuk didalamnya BMT seperti yang diungkapkan dibawah ini :

Dana Nasabah Rp. 6,8 Miliar Tertahan di BMT Sabilillah Slogobimo. Dikutip dari media online harianjogja.com (Soeparno, 2017) Sejumlah nasabah Baitul Maal Wat Tamwil (BMT) Sabilillah Slogohimo geram lantara dana deposito mereka tidak bisa dicairkan. Total dana yang dihimpun dari 240 nasabah tersebut mencapai Rp. 6,8 milyar. Ketua Tim Likuiditas BMT 
Sabilillah Slogohimo, Soeparno, melalui salah satu anggota Tim Likuditas BMT Sabilillah Slogohimo, Kun Pratowo, mendapat laporan dari 240 nasabah BMT Sabilillah Slogohimo yang tidak bisa mencairkan deposito. Tim Likuiditas BMT Sabilillah Slogohimo merupakan tim likuidasi yang dibentuk Dinas Koperasi Usaha Kecil dan Menegah dan Perindustrian dan Perdagangan (Dinkop UKM Perindag) Wonogiri dan Polres Wonogiri pada 23 Januari 2017. Seperti halnya kasus diatas masalah likuiditas juga terdapat di wilayah Kalimantan Barat terutama di Kota Pontianak. Berikut ini ringkasan laporan keuangan berupa neraca dari Baitul Mal-Wattamwil (BMT) Kapuas Mandiri Sejahtera dari tahun 2013-2017.

Tabel. 1: Baitul Maal-Wattamwil Kapuas Mandiri Sejahtera Pontianak Neraca Komparasi Tahun 2013-2017 (dalam jutaan rupiah)

\begin{tabular}{ccccc}
\hline \multirow{2}{*}{ Tahun } & Kas dan Bank & $\begin{array}{c}\text { Kewajiban } \\
\text { Lancar }\end{array}$ & $\begin{array}{c}\text { Total } \\
\text { Pembiayaan }\end{array}$ & $\begin{array}{c}\text { Total Dana } \\
\text { Pihak Ke-3 }\end{array}$ \\
\cline { 2 - 6 } & \multicolumn{2}{c}{$(\mathbf{R p . )}$} & \multicolumn{2}{c}{$\mathbf{( R p . )}$} \\
\hline 2013 & $70.385 .327,00$ & $144.253 .175,33$ & $372.062 .374,00$ & $144.253 .175,33$ \\
2014 & $255.760 .285,60$ & $863.444 .028,30$ & $690.327 .026,40$ & $862.892 .367,16$ \\
2015 & $547.806 .080,60$ & $904.065 .970,70$ & $533.124 .233,87$ & $903.426 .459,96$ \\
2016 & $126.573 .941,50$ & $499.607 .531,60$ & $515.057 .378,35$ & $523.968 .020,86$ \\
2017 & $130.996 .092,00$ & $411.810 .396,00$ & $493.732 .902,63$ & $411.170 .885,56$ \\
\hline
\end{tabular}

Sumber : Laporan Keuangan BMT Kapuas Mandiri Sejahtera, Tahun 2017.

Berdasarkan Tabel.1 terlihat jelas Baitul Maal-Wattamwil (BMT) Kapuas Mandiri Sejahterah Pontianak terus mengalami fluktuasi. Dapat dilihat pada tahun 2013 kas yang dimiliki sebesar Rp. 70.385.327,00 sedangkan kewajiban yang harus dipenuhi sebesar Rp. 144.253.175,33. Pada tahun 2014 dan 2015 jumlah kas dan bank meningkat begitu juga jumlah kewajiban lancar, namun pada tahun 2016 dan 2017 jumlah kas dan bank menurun begitu juga jumlah kewajiban lancar. Total Pembiayaan ditahun 2013 sebesar Rp. 372.062.374,00 sedangkan total dana pihak ketiga sebesar Rp. 144.253.175,33. Pada tahun 2014 jumlah pembiayaan meningkat begitu juga jumlah dana pihak ketiga, namun pada tahun 2015 sampai dengan 2017 jumlah pembiayaan selalu menurun begitu juga jumlah tota dana pihak ketiga.

Beberapa penelitian yang terkait dengan penelitian yang dilakukan diantaranya adalah Albahi, M (2015). dalam jurnalnya yang berjudul Analisis Rasio Likuiditas, Rasio Rentabilitas, Rasio Solvabilitas Pada Kinerja Keuangan Pt. Bank Sumut Cabang Pimbagi Medan. Maya Puspitasari, 2014. Analisis Rasio Likuiditas, Permodalan Dan Manajemen di KSPS BMT Logam Mulia. Barus, AC. (2011) Analisis Profitabilitas Dan Likuiditas Terhadap Capital Adequacy Ratio (CAR) Pada Institusi Perbankan Terbuka di Bursa Efek Indonesia. Tampubolon, L. (2015) Analisis Pengaruh Rasio Keuangan: Likuiditas, Aktivitas dan Leverage Terhadap Penilaian Kinerja Keuangan Studi Empiris: Perusahaan Manufaktur di Bursa Efek Indonesia Periode 2010 - 2012. Amanah, R.,Atmanto, D., Aziza, DF. (2014). Pengaruh Rasio Likuiditas Dan Rasio Profitabilitas Terhadap Harga SAHAM (Studi pada Perusahaan Indeks LQ45 Periode 2008-2012). Palamai Srinivasan, P., \& Britto, J. (2017). Analysis of Financial Performance of Selected Commercial Banks in India.Theogene.,H., dkk, (2017). The Contribution Of Financial Ratios Analysis On Effective Decision Making In Commercial Bank. Costea, CD., \& Hostiuc, F. (2009). The Liquidity Ratios And Their Significance In The Financial Equilibrium Of The Firms. Tugas, FC. (2012). A Comparative Analysis of the. Financial Ratios of Listed Firms Belonging to the Education Subsector in the Philippines for the Years 2009-2011, Lartey, VC., Antwi1, S., \& Boadi, EB. (2013). The Relationship between Liquidity and Profitability of Listed Banks in Ghana Victor Curtis Lartey. Djafar, S. (2008), Rasio Likuiditas, Profibilitas dan Efisiensi Pada Koperasi Serba Usaha Bait Al-Maal Wa At Tamwil Madinah dan Ikhwanul Mukminin Pontianak. Kusdianto, 
Muhammad Syaifullah, et al. Metode Kuadrat Terkecil Untuk Meramalkan...

D. (2007). Analisis Rasio Likuiditas dan Profibilitas pada Baitul Maal-Wattamwil Mujahidin dan Aisyiyah Pontianak.

Kebaharuan penelitian yang dilakukan dengan penelitian sebelumnya adalah pada tempat penelitian, periode penelitian, teori yang di gunakan ada perbedaan, jurnal nasional dan jurnal internasional yang menjadi referensi terdapat perbedaan, statement dari para para pakar yang berbeda dan dari media bonafit yang berbeda.

\section{LANDASAN TEORI}

\section{Laporan Keuangan}

Salah satu sumber informasi penting yang digunakan manajemen dalam pengambilan keputusan tersebut, terutama keputusan keuangan adalah laporan keuangan. Laporan keuangan juga menunjukkan apa yang telah dilakukan manajemen atau mempertanggung jawaban manajemen atas sumber daya yang dipercayakan kepadanya (Najmudin, 2011). Seperti yang dijelaskan dalam Al- Quran Surah $A l$ : Muthaffifin Ayat 1-3 dibawah ini :

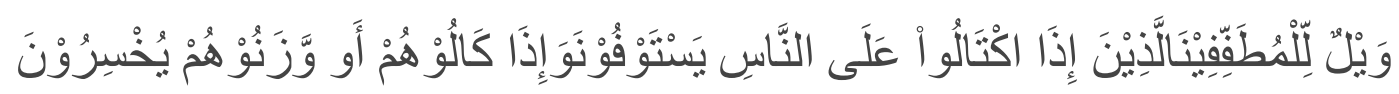

Terjemahnya:

"Kecelakaan besarlah bagi orang-orang yang curang, (yaitu) orang-orang yang apabila menerima takaran dari orang lain mereka minta dipenubi, dan apabila mereka menakar atau menimbang untuk, orang lain, mereka mengurangi." (QR. Al: Muthaffifin 1-3)

Laporan keuangan adalah hasil akhir dari proses transaksi keuangan yang terjadi selama 1 (satu) periode akuntansi dan merupakan pertanggungjawaban manajemen di dalam mengelola sebuah organisasi (Najmudin, 2011; Harjito, A, 2011; Sirait, P. 2014; QR. Al: Muthaffifin 1-3). Analisis laporan keuangan adalah analisis mengenai kondisi keuangan yang bersifat menyeluruh, dapat digunakan untuk mendeteksi tingkat kesehatan suatu perusahaan. (Harmono, 2009; Harjito, A, 2011; Najmudin, 2011).

Rasio keuangan merupakan perbandingan angka-angka yang yang terdapat di dalam laporan keuangan sebuah organisasi pada periode akuntansi tertentu (Kasmir, 2010; Keown, Arthur J, dkk, 2011:74;). Analisis rasio keuangan adalah barometer kesehatan keuangan perusahaan dan dapat menunjukkan potensi masalah sebelum berkembang menjadi krisis yang serius serta menghubungkan unsur-unsur neraca dan perhitungan laba rugi satu dengan lainnya, dapat memberikan gambaran tentang sejarah perusahaan dan penilaian posisinya pada saat ini (Sulindawati, NLGE., dkk, 201; Najmudin, 2011).

Rasio likuiditas merupakan rasio yang menunjukkan kemampuan suatu perusahaan di dalam memenuhi kewajiban jangka pendek perusahaan, dengan membandingkan antara total asset lancar dengan kewajiban lancar (Harjito, A, 2011; Sulindawati, NLGE., dkk, 2017; Jopie J, 2014; Kasmir, 2015).

Dalam Rasio pembiayaan, alat yang digunakan untuk mengukur likuiditas dalam membayar kembali penarikan dana dengan membandingkan antara total pembiayaan dengan dana yang diterima.

Rumus :

$$
\mathrm{FDR}=\frac{\text { Total Pembiayaan }}{\text { Dana yang diterima }} \times 100 \%
$$

Ukuran Penilaian :

Tidak likuid $\quad: \quad<50$

Kurang likuid : $\quad 51-74$

Cukup likuid : 75-99 
AL-MASHRAFIYAH: Jurnal Ekonomi, Keuangan, dan Perbankan Syariah Volume 3, Nomor 1, April 2019

Likuid : $\quad>99$

Sumber: (Permenkop Nomor : 07/Per/Dep.6/IV/2016 Tentang Pedoman Penilaian Kesehatan Koperasi Simpan Pinjam \& Pembiayaan Syariah Koperasi; Ikatan Bankir Indonesia 2016; dan Suryani 2011).

\section{Analisis Trend}

"Analisis trend atau tendensi merupakan analisis laporan keuangan yang biasanya dinyatakan dalam persentase tertentu." (Kasmir 2016).

Ada empat cara yang dapat digunakan untuk menentukan persamaan trend linear, yaitu:

1. Metode bebas

2. Metode setengah rata-rata

3. Metode rata-rata bergerak

4. Metode kuadrat terkecil

Keempat cara ini dipakai untuk menentukan bentuk umum persamaan trend linear, yaitu:

$\mathrm{Y}=\mathrm{a}+\mathrm{bX}$

Keterangan:

Y : Nilai trend pada periode tertentu (variabel tak bebas).

$\mathrm{X}$ : Periode waktu (variabel bebas).

a : Intersep dari persamaan trend.

b : Koefisien kemiringan atau gradien dari persamaan trend yang menunjukkan besarnya perubahan $\mathrm{Y}$ bila terjadi perubahan satu unit pada X (Boediono \& Koster, 2002, dalam Ranny Fitriana, 2017).

Terdapat beberapa metode yang umum digunakan untuk menggambarkan garis trend. Beberapa diantaranya :

1. Metode tangan bebas

2. Metode rata-rata semi

3. Metode rata-rata bergerak

4. Metode kuadrat terkecil

Metode kuadrat terkecil untuk mencari garis trend dimaksudkan suatu perkiraan atau taksiran mengenai nilai a dan $b$ dari persamaan $\mathbf{Y}=\mathbf{a}+\mathbf{b X}$ yang didasarkan atas data hasil observasi sedemikian rupa, sehingga dihasilkan jumlah kesalahan kuadrat terkecil (minimum) (Supranto, 2008:236).

\section{Baitul Maal Wat-Tamwil (BMT)}

BMT adalah lembaga keuangan mikro yang dioperasikan dengan prinsip bagihasil, menumbuh kembangkan bisnis usaha mikro dalam rangka mengangkat derajat martabat serta membela kepentingan kaum fakir miskin (Muhammad, 2007; Rivai, V, dkk, 2013; Arif, NRA. 2012). Fungsi BMT adalah meningkatkan kualitas SDM anggota, pengurus, dan pengelola menjadi lebih profesional, salaam (selamat, damai, dan sejahtera), dan amanah sehingga semakin utuh dan tangguh dalam berjuang dan berusahan beribadah menghadapi tantangan global sumber pendapatan, bmt dapat menciptakan lapangan kerja dan memberi pendapatan kepada pegawainya. Pemberi informasi kepada masyarakat mengenai risiko keuntungan dan peluang yang ada pada lembaga tersebut (Arif, NRA, 201; Soemitra, 2009; Rivai, V, dkk, 2013).

\section{METODE PENELITIAN}

Penelitian ini menggunakan pendekatan deskriptif dengan menggunakan pendekatan kuantitatif. Penelitian ini dilakukan untuk memberikan gambaran yang lebih detail mengenai suatu gejala atau fenomena. Tujuan dari penelitian deskripsi adalah menggambarkan 
Muhammad Syaifullah, et al. Metode Kuadrat Terkecil Untuk Meramalkan...

mekanisme sebuah proses dan menciptakan seperangkat kategori atau pola (Prasetyo, B, 2005). Penelitian deskriptif menuturkan dan menafsirkan data yang berkenaan dengan fakta, keadaan, variabel, dan fenomena yang terjadi saat penelitian berlangsung dan menyajikan apa adanya (Subana, 2005). Metode kuadrat terkecil untuk mencari garis trend dimaksudkan suatu perkiraan atau taksiran mengenai nilai a dan $b$ dari persamaan $\mathrm{Y}=\mathrm{a}+\mathrm{bX}$ yang didasarkan atas data hasil observasi sedemikian rupa, sehingga dihasilkan jumlah kesalahan kuadrat terkecil (minimum) (Supranto, 2008).

\section{HASIL DAN PEMBAHASAN}

\section{Analisis Rasio Likuiditas}

\section{Tingkat Likuiditas}

a. Rasio Kas (Cash Ratio)

Cash Ratio adalah alat yag digunakan untuk mengetahui seberapa besar uang kas yang tersedia untuk membayar utang lancar (Sulindawati, NLGE., dkk, 2017:139; Kasmir 2015:138139; Permenkop Nomor : 07/Per/Dep.6/IV/2016 Tentang Pedoman Penilaian Kesehatan Koperasi Simpan Pinjam \& Pembiayaan Syariah Koperasi)

Rumus :

$$
\text { Cash Ratio }=\frac{\text { Kas }+ \text { Bank }}{\text { Kewajiban }} \times 100 \%
$$

Sebelum menghitung cash ratio pada BMT Kapuas Mandiri Sejahtera dari tahun 2013 sampai dengan 2017. Terlebih dahulu penulis paparkan komponen komponen unruk mengetahui cash ratio pada Tabel 4.1 berikut ini :

\section{Tabel 2: Persentase Kenaikan/penurunan Cash Ratio BMT Kapuas Mandiri Sejahtera Pontianak, Tahun 2013-2017}

\begin{tabular}{ccccc}
\hline Tahun & Kas dan Bank & Kewajiban Lancar & $\begin{array}{c}\text { Cash } \\
\text { Ratio }\end{array}$ & $\begin{array}{c}\text { Kriteria } \\
\text { (Permenkop Nomor : } \\
\text { o7/Per/Dep.6/IV/2016) }\end{array}$ \\
\hline 2013 & Rp.70.385.327,00 & Rp.144.253.175,33 & 48,79 & $\begin{array}{c}(50 \times 10=5) \\
\text { Kurang Likuid } \\
(100 \times 10=10) \\
\text { Likuid }\end{array}$ \\
2014 & Rp.255.760.285,60 & Rp.863.444.028,30 & 29,62 & $\begin{array}{c}(25 \times 10=2,5) \\
\text { Tidak Likuid }\end{array}$ \\
2015 & Rp.547.806.080,60 & Rp.904.065.970,70 & 60,59 & $\begin{array}{c}75 \times 10=7,5) \\
\text { Cukup Likuid } \\
(100 \times 10=10) \\
\text { Likuid }\end{array}$ \\
\hline
\end{tabular}

Sumber: Olah Data Sekunder, Tahun 2018

Dari hasil perhitungan di atas kewajiban BMT untuk memenuhi kebutuhan jangka pendeknya pada tahun 2013 sebesar 48,79\% atau sebesar 49\% yang berarti setiap Rp.1,00 kewajiban lancar yang ditanggung oleh koperasi mampu dijamin oleh Rp. 0,49 dari kas dan bank. Pada tahun 2013 perusahaan mendapatkan kriteria Kurang Likuid. Pada tahun 2014 Cash Ratio sebesar 29,62\% atau sebanyak 30\% yang berarti setiap Rp.1,00 kewajiban lancar yang ditanggung oleh koperasi, mampu dijamin oleh Rp. 0,30 dari kas dan bank. Pada tahun 2014 perusahaan memperoleh kriteria Likuid. Pada tahun 2015, terjadi peningkatan Cash Ratio menjadi 60,59\% atau sebesar 61\%, yang berarti setiap Rp.1,00 kewajiban yang ditanggung 
oleh koperasi mampu dijamin oleh Rp. 0,61 dari kas dan bank. Pada tahun 2015, perusahaan memperoleh kriteria Tidak Likuid. Pada tahun 2016 Cash Ratio menurun menjadi sebesar 25,33 \% berarti setiap Rp.1,00 kewajiban lancar yang ditanggung oleh koperasi mampu dijamin oleh Rp. 0,25 dari kas dan bank, pada tahun 2016 perusahaan mendapatkan kriteria Cukup Likuid. Pada tahun 2017 Cash Ratio mengalami peningkatan menjadi sebesar Rp. 31,81 \% atau $32 \%$ yang berarti setiap Rp.1,00 kewajiban lancar yang ditanggung oleh koperasi mampu dijamin oleh Rp. 0,32 kas dan bank. Pada tahun 2017, perusahaan mendapatkan kriteria Likuid. Informasi dari Tabel. 3, sesuai, sejalan atau mendukung hasil penelitian dari 1) Maya Puspitasari, 2014; terkait dengan nilai kinerja keuangan yang hasilnya bervariasi; 2) Lambok Tampubolon, 2015; rasio likuiditas berpengaruh secara signifikan dalam mengukur kinerja keuangan; 3) Habimana Theogene dkk, 2017; analisis rasio kualitas aset mempengaruhi pengambilan keputusa; 4) Ciprian dan Costea, 2009; pentingnya analisis keuangan yang mendalam dan terperinci dengan menggunakan rasio likuiditas; 5) Florenz, 2012; analisa rasio keuangan yang komprehensif akan berdampak pada nilai pasar; 6) SY. Djafar, 2008; terdapat peningkatan dan penurunan kinerja keuangan; dan 7) Deny Kusdianto, 2007, terdapat perbedaan kinerja pada quick rasio.

\section{b. Rasio Pembiayaan (Financing To Deposit Ratio / FDR)}

Rasio Pembiayaan adalah alat yang digunakan mengukur likuiditas dalam membayar kembali penarikan dana dengan membandingkan antara total pembiayaan dengan dana yang diterima. (Permenkop Nomor : 07/Per/Dep.6/IV/2016 Tentang Pedoman Penilaian Kesehatan Koperasi Simpan Pinjam \& Pembiayaan Syariah Koperasi, Ikatan Bankir Indonesia 2016, Suryani 2011).

Rumus :

$$
\mathrm{FDR}=\frac{\text { Total Pembiayaan }}{\text { Dana yang diterima }} \times 100 \%
$$

Sebelum menghitung FDR pada BMT Kapuas Mandiri Sejahtera dari tahun 2013 sampai dengan 2017. Terlebih dahulu penulis paparkan komponen komponen unruk mengetahui FDR pada tabel 4.8 berikut ini :

Tabel 3: BMT Kapuas Mandiri Sejahtera Pontianak Persentase Kenaikan / Penurunan FDR

\begin{tabular}{ccccc}
\hline Tahun & $\begin{array}{c}\text { Total } \\
\text { Pembiayaan }\end{array}$ & $\begin{array}{c}\text { Total Dana } \\
\text { Pihak Ke-3 }\end{array}$ & FDR & $\begin{array}{c}\text { Kriteria } \\
\text { (Permenkop Nomor : } \\
\text { o7/Per/Dep.6/IV/2016) }\end{array}$ \\
\cline { 2 - 5 } & \multicolumn{2}{c}{ Rupiah (Rp.) } & Persentase (\%) \\
\hline 2013 & $372.062 .374,00$ & $144.253 .175,33$ & 257,92 & $(100 \times 5=5)$ Likuid \\
2014 & $690.327 .026,40$ & $862.892 .367,16$ & 80,00 & $(75 \times 5=3,75)$ Cukup Likuid \\
2015 & $533.124 .233,87$ & $903.426 .459,96$ & 59,01 & $(50 \times 5=2,50)$ Kurang Likuid \\
2016 & $515.057 .378,35$ & $523.968 .020,86$ & 98,30 & $(100 \times 5=5)$ Likuid \\
2017 & $493.732 .902,63$ & $411.170 .885,56$ & 120,08 & $(100 \times 5=5)$ Likuid \\
\hline
\end{tabular}

Sumber : Olah Data Sekunder BMT Kapuas Mandiri Sejahtera, 2018.

Dari hasil perhitungan tersebut diketahui bahwa kewajiban BMT untuk membayar kembali kepada deposannya dari tahun 2013 - 2017 mengalami fluktuasi pada tahun 2013 sebesar 257,92\% atau 258\% yang berarti setiap Rp.1,00 dana pihak ketiga dapat dapat dibayar dengan Rp. 2,58 dari total pembiayaan. Pada tahun 2013, FDR dalam kriteria Likuid. Pada 
Muhammad Syaifullah, et al. Metode Kuadrat Terkecil Untuk Meramalkan...

tahun 2014 menjadi sebesar 80,00\% atau menurun sebanyak 68,98\% yang berarti setiap Rp.1,00 dana pihak ketiga dapat dapat dibayar dengan Rp. 0,80 dari total pembiayaan. Pada tahun 2014, FDR masuk dalam kriteria Cukup Likuid. Pada tahun 2015 FDR sebesar 59,01\% atau menurun sebanyak $-26,24 \%$ yang berarti setiap Rp.1,00 dana pihak ketiga dapat dapat dibayar dengan Rp. 0,59 dari total pembiayaan. Pada tahun 2015, FDR dalam kriteria Kurang Likuid. Pada tahun 2016 FDR sebesar $98,16 \%$ atau meningkat sebanyak 66,48 \% yang berarti setiap Rp.1,00 dana pihak ketiga dapat dapat dibayar dengan Rp. 0,98 dari total pembiayaan. Pada tahun 2016, FDR pada peringkat Likuid. Pada tahun 2017 menjadi sebesar Rp. 119,8 \% atau meningkat sebanyak 22,04 \% yang berarti setiap Rp.1,00 dana pihak ketiga dapat dapat dibayar dengan Rp. 0,19 dari total pembiayaan. Pada tahun 2017 FDR memperoleh kriteria Likuid.

Hasil olah data sekunder pada Tabel. 4, mendukung hasil penelitian dari 1) Maya Puspitasari, 2014; terkait dengan nilai kinerja keuangan yang hasilnya bervariasi; 2) Lambok Tampubolon, 2015; rasio likuiditas berpengaruh secara signifikan dalam mengukur kinerja keuangan; 3) Habimana Theogene dkk, 2017; analisis rasio kualitas aset mempengaruhi pengambilan keputusa; 4) Ciprian dan Costea, 2009; pentingnya analisis keuangan yang mendalam dan terperinci dengan menggunakan rasio likuiditas; 5) Florenz, 2012; analisa rasio keuangan yang komprehensif akan berdampak pada nilai pasar; 6) SY. Djafar, 2008; terdapat peningkatan dan penurunan kinerja keuangan; dan Hardono, D.H. (2010).

\section{Analisis Likuiditas Menggunakan Metode Kuadrat Terkecil}

\section{a. Rasio Kas (Cash Ratio)}

Tingkat Likuiditas di atas dilanjutkan dengan analisis likuditas Trend Cash Ratio BMT Kapuas Mandiri Sejahtera Pontianak, sebagai berikut:

Tabel 4: Analisis Trend Dengan Metode Kuadrat Terkecil Cash Ratio, BMT Kapuas Mandiri Sejahtera

\begin{tabular}{|c|c|c|c|c|c|c|c|}
\hline Tahun & $\mathbf{X}$ & $\mathbf{Y}$ & $\mathbf{X Y}$ & $\mathbf{X}^{2}$ & Cash Ratio & $\begin{array}{l}\text { Nilai } \\
\text { Trend }\end{array}$ & Kriteria \\
\hline 2013 & -2 & 48,79 & $-97,58$ & 4 & 48,79 & 46,88 & Kurang Likuid \\
\hline 2014 & -1 & 29,62 & $-29,62$ & 1 & 29,62 & 43,05 & Likuid \\
\hline 2015 & 0 & 60,59 & 0,00 & 0 & 60,59 & 39,23 & Tidak Likuid \\
\hline 2016 & 1 & 25,33 & 25,33 & 1 & 25,33 & 35,40 & Cukup likuid \\
\hline \multirow[t]{2}{*}{2017} & 2 & 31,81 & 63,62 & 4 & 31,81 & 31,58 & Likuid \\
\hline & $\begin{array}{l}\sum \mathrm{X} \\
=0\end{array}$ & $\begin{aligned} & \sum Y \\
= & Y 96,14\end{aligned}$ & $\begin{aligned} & \sum X Y \\
= & -38,25\end{aligned}$ & $\begin{array}{l}\sum X^{2} \\
=10\end{array}$ & & & \\
\hline
\end{tabular}

Sumber: Olah data sekunder BMT Kapuas Mandiri Sejahtera, Tahun 2018

$$
\begin{aligned}
& \mathrm{a}=\frac{\Sigma \mathrm{Y}}{n}=\frac{196,14}{5}=39,23 \\
& \mathrm{a}=\frac{\Sigma \mathrm{XY}}{\Sigma \mathrm{X}_{2}}=\frac{-38,25}{10}=-3,83
\end{aligned}
$$

Jadi,

adalah $\mathrm{Y}=39,228+-3,825$. Dengan demikian persamaan

trend tersebut kita dapat menentukan nilai-nilai trend untuk setiap nilai $\mathrm{x}$.

Untuk X $=-2$ Tahun 2013, maka nilai trendnya adalah

$\mathrm{Y}=39,228+-3,825(-2)=46,88$

Untuk X = -1 Tahun 2014, maka nilai trendnya adalah 
AL-MASHRAFIYAH: Jurnal Ekonomi, Keuangan, dan Perbankan Syariah Volume 3, Nomor 1, April 2019

$Y=39,228+-3,825(-1)=43,05$

Untuk $\mathrm{X}=0$ Tahun 2015, maka nilai trendnya adalah

$\mathrm{Y}=39,228+-3,825(0)=39,23$

Untuk $\mathrm{X}=1$ Tahun 2016, maka nilai trendnya adalah

$\mathrm{Y}=39,228+-3,825(1)=35,40$

Untuk $X=2$ Tahun 2017, maka nilai trendnya adalah

$\mathrm{Y}=39,228+-3,825(2)=31,58$

Untuk lebih memperjelas kita perhatikan grafik persamaan trend $\mathrm{Y}=35,22+6,47 \mathrm{X}$ yang disatukan dengan grafik data berkala pada gambar berikut :

Gambar 1: Analisis Trend Cash Ratio

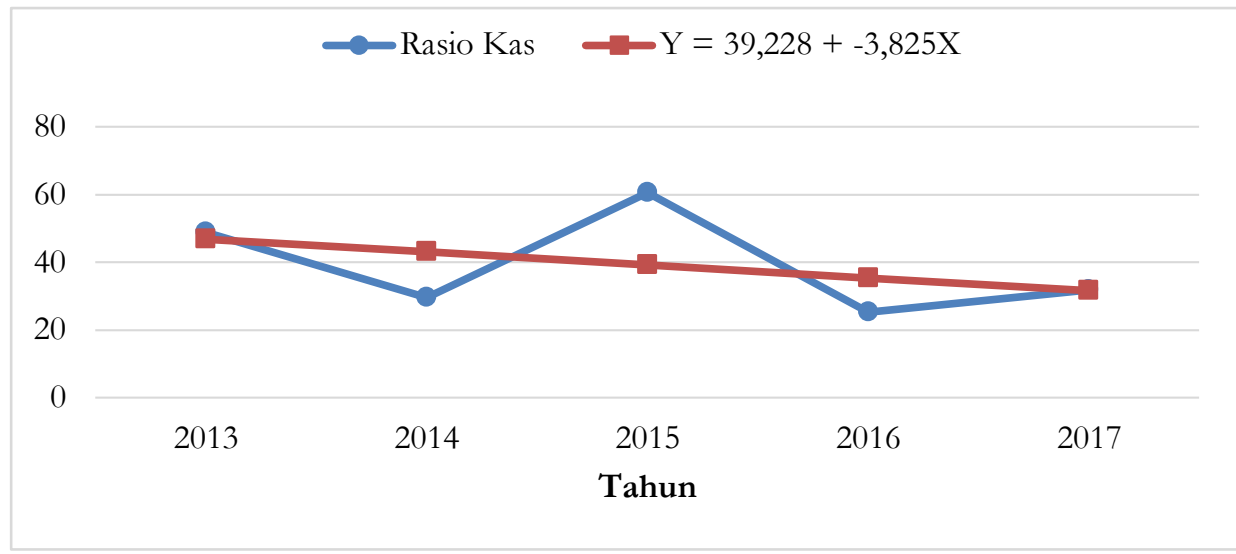

Sumber: Olah data sekunder BMT Kapuas Mandiri Sejahtera, Tahun 2018

Dari grafik di atas terlihat terjadi fluktuasi pada cash ratio di BMT dan untuk grafik persamaannya memiliki kecenderungan menurun. Artinya tingkat cash ratio di BMT menurun sebesar 0,57 setiap tahunnya. Keadaan yang demikian menunjukkan bahwa penggunaan kas BMT Kapuas Mandiri Sejahtera Pontianak dari tahun 2013 sampai dengan 2017 mengalami penurunan. Hasil perhitungan cash ratio pada tahun 2013 sebesar 48,79\% dikatakan Kurang Likuid karena berada pada rentang (14-20) dan (46-56). Pada tahun 2014 sebesar 29,62\% dikatakan Likuid karena berada pada rentang (26-34). Pada tahun 2015 sebesar 60,59\% dikatakan Tidak Likuid karena berada pada rentang $<14$ dan $>$ 56. Tahun 2016 sebesar 25,33\% dikatakan Cukup Likuid karena berada pada rentang (21-25) dan (35-45). Pada tahun 2017 sebesar 31,81\% dikatakan Likuid karena berada pada rentang (26-34).

Hasil penelitian sejalan dengan hasil penelitian yang dilakukan diantaranya oleh Indrawati, A. (2017) dimana didalam analisis trend dengan kuadrat terkecil mampu memberikan informasi terkait kinerja keuangan dalam sebuah organisasi. Dimana informasi tersebut mampu memberikan informasi kepada pengambilan keputusan misalnya dari fihak manajemen, anggota BMT, dan kriditur.

\section{b. Rasio Pembiayaan (Financing To Deposit Ratio / FDR)}

Tingkat Likuiditas di atas dilanjutkan dengan analisis likuditas Trend FDR BMT Kapuas Mandiri Sejahtera Pontianak, sebagai berikut: 
Muhammad Syaifullah, et al. Metode Kuadrat Terkecil Untuk Meramalkan...

Tabel 5: Analisis Trend Dengan Metode Kuadrat Terkecil Rasio FDR, BMT Kapuas Mandiri Sejahtera

\begin{tabular}{cccccccc}
\hline Tahun & $\mathbf{X}$ & $\mathbf{Y}$ & $\mathbf{X Y}$ & $\mathbf{X}^{2}$ & $\begin{array}{c}\text { Rasio } \\
\text { FDR }\end{array}$ & $\begin{array}{c}\text { Nilai } \\
\text { Trend }\end{array}$ & Kriteria \\
\hline 2013 & -2 & 257,92 & $-515,84$ & 4 & 257,92 & 174,54 & Likuid \\
2014 & -1 & 80 & $-80,00$ & 1 & 80 & 148,80 & Cukup Likuid \\
2015 & 0 & 59,01 & 0,00 & 0 & 59,01 & 123,06 & Kurang Likuid \\
2016 & 1 & 98,3 & 98,30 & 1 & 98,3 & 97,32 & Cukup Likuid \\
2017 & 2 & 120,08 & 240,16 & 4 & 120,08 & 71,59 & Likuid \\
\hline & $\sum \mathrm{X}$ & $\sum \mathrm{Y}$ & $\sum \mathrm{XY}$ & $\sum \mathrm{X}^{2}$ & & & \\
& $=0$ & $=615,31$ & $=-257,38$ & $=10$ & & & \\
\hline
\end{tabular}

Sumber : Olah data sekunder BMT Kapuas Mandiri Sejahtera, Tahun 2018

$$
\begin{aligned}
& a=\frac{\Sigma Y}{n}=\frac{615,31}{5}=123.06 \\
& a=\frac{\Sigma Y}{\Sigma X_{2}}=\frac{615,31}{5}=-25,74
\end{aligned}
$$

Jadi, persamaan trendnya adalah $\mathrm{Y}=123,06-25,74 \mathrm{X}$. Dengan demikian persamaan trend tersebut kita dapat menentukan nilai-nilai trend untuk setiap nilai $\mathrm{x}$.

Untuk X $=-2$ Tahun 2013, maka nilai trendnya adalah

$\mathrm{Y}=123,06-25,74 \mathrm{X}(-2)=174,54$

Untuk X $=-1$ Tahun 2014, maka nilai trendnya adalah

$\mathrm{Y}=123,06-25,74 \mathrm{X}(-1)=148,80$

Untuk $\mathrm{X}=0$ Tahun 2015, maka nilai trendnya adalah

$\mathrm{Y}=123,06-25,74 \mathrm{X}(0)=123,06$

Untuk X = 1 Tahun 2016, maka nilai trendnya adalah

$\mathrm{Y}=123,06-25,74 \mathrm{X}(1)=97,32$

Untuk $\mathrm{X}=2$ Tahun 2017, maka nilai trendnya adalah

$\mathrm{Y}=123,06-25,74 \mathrm{X}(2)=71,59$

Untuk lebih memperjelas kita perhatikan grafik persamaan trend $\mathrm{Y}=123,06-25,74 \mathrm{X}$ yang disatukan dengan grafik data berkala pada gambar berikut :

Gambar 2: Analisis Trend Rasio FDR

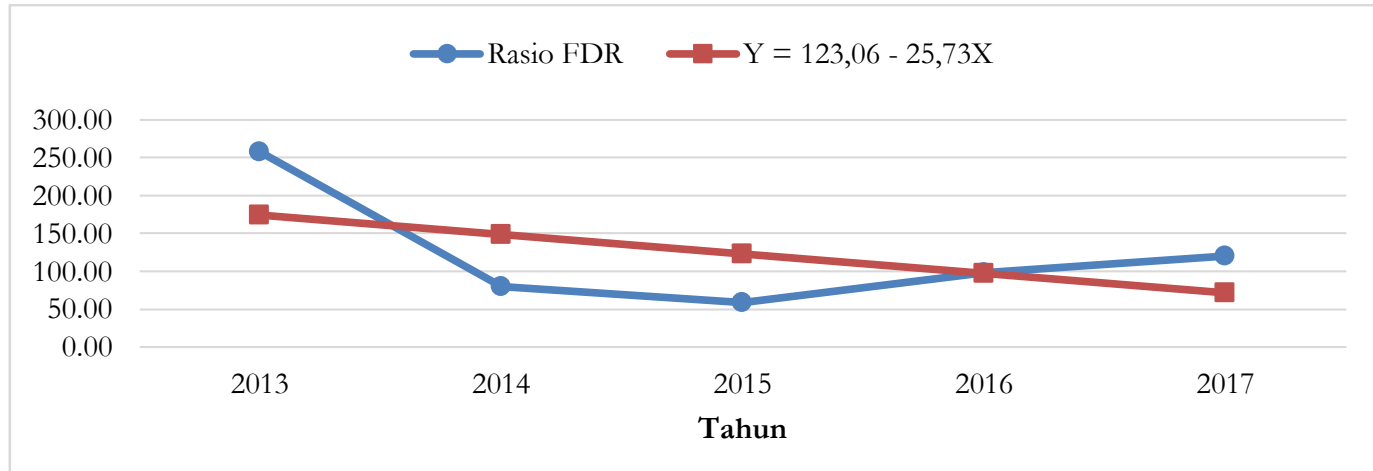

Sumber: Olah data sekunder BMT Kapuas Mandiri Sejahtera, Tahun 2018. 
Dari grafik di atas terlihat terjadi fluktuasi pada Rasio FDR di BMT dan untuk grafik persamaannya memiliki kecenderungan menurun. Artinya tingkat Rasio FDR di BMT menurun sebesar 25,73 setiap tahunnya. Keadaan yang demikian menunjukkan bahwa pembiayaan BMT Kapuas Mandiri Sejahtera Pontianak dari tahun 2013 sampai dengan 2017 mengalami penurunan.

Hasil perhitungan FDR pada tahun 2013 sebesar 257,92\% dikatakan Likuid karna berada pada rentang >99. Pada tahun 2014 sebesar 80,00\% dikatakan Cukup Likuid karena berada pada rentang 75-99. Pada tahun 2015 sebesar 59,01\% dikatakan Kurang Likuid karena berada pada rentang 50-74. Tahun 2016 sebesar 98,30\% dikatakan Cukup Likuid karena berada pada rentang 75-99. Pada tahun 2017 sebesar 120,08\% dikatakan Likuid karna berada pada rentang $>99$.

Hasil penelitian sejalan dengan hasil penelitian yang dilakukan diantaranya oleh Indrawati, A. (2017) dimana didalam analisis trend dengan kuadrat terkecil mampu memberikan informasi terkait trend kinerja keuangan dalam sebuah organisasi. Dimana informasi tersebut mampu memberikan informasi kepada pengambilan keputusan dari manajemen, kreditur maupun dari pihak investor.

\section{PENUTUP}

Analisis Likuiditas a) Cash ratio tahun 2013 sebesar 48,79 persen dikatakan Kurang Likuid karena berada pada rentang (14-20) dan (46-56). Pada tahun 2014 sebesar 29,62 persen dikatakan Likuid karena berada pada rentang (26-34). Pada tahun 2015 sebesar 60,59 persen dikatakan Tidak Likuid karena berada pada rentang <14 dan $>56$. Tahun 2016 sebesar 25,33 persen dikatakan Cukup Likuid karena berada pada rentang (21-25) dan (35-45). Pada tahun 2017 sebesar 31,81 persen dikatakan Likuid karena berada pada rentang (26-34); b) Rasio FDR, pada tahun 2013 sebesar 257,92 persen dikatakan Likuid karna berada pada rentang >99. Pada tahun 2014 sebesar 80 persen dikatakan Cukup Likuid karena berada pada rentang 75-99. Pada tahun 2015 sebesar 59,01 persen dikatakan Kurang Likuid karena berada pada rentang 50-74. Tahun 2016 sebesar 98,30 persen dikatakan Cukup Likuid karena berada pada rentang 75-99. Pada tahun 2017 sebesar 120,08 persen dikatakan Likuid karna berada pada rentang $>99$.

Analisis Menggunakan Metode Kuadrat Terkecil a) Dari analisa cash ratio dari tahun 2013 sampai dengan 2017 di atas terlihat bahwa kemampuan kas di BMT dalam menghasilkan pendapatan pada mengalami fluktuasi. Untuk analisis trend metode kuadrat terkecil menunjukkan bahwa kas BMT memiliki kecenderungan untuk menurun yang artinya ada penurunan dari tahun 2013 sampai dengan 2017. Dari analisa rasio FDR dari tahun 2013 sampai dengan 2017 di atas terlihat bahwa kemampuan pembiayaan di BMT dalam menghasilkan pendapatan mengalami fluktuasi. Untuk analisis trend metode kuadrat terkecil menunjukkan bahwa pembiayaan BMT memiliki kecenderungan untuk menurun yang artinya ada penurunan dari tahun 2013 sampai dengan 2017.

Saran kepada Manajemen BMT, untuk meningkatkan jumlah kas; meningkatkan prinsip kehati-hatian dalam hal pemberian pembiayaan untuk meminimalisirkan resiko piutang tak tertagih; menurunkan hutang lancar; meningkatkan pembiayaan, serta untuk peneliti selanjutnya disarankan untuk mengembangkan penelitian ini dengan menambah jumlah rasio yang diteliti misalnya rasio rentabilitas, profitabilitas, aktivitas, solvabilitas, dll dan juga disarankan untuk meneliti seluruh BMT yg beroperasi di diseluruh wilayah Indonesia. 
Muhammad Syaifullah, et al. Metode Kuadrat Terkecil Untuk Meramalkan...

\section{DAFTAR PUSTAKA}

Abdullah, T \& Francis, T. (2014). BANK dan Lembaga Kenangan. Jakarta: PT Raja Grafindo Persada.

Abror, Achmad, Elly Santi, Omposunggu, Frianto, Pandia. (2005) Lembaga Keuangan, Jakarta: PT. Rineka Cipta. (2005) Lembaga Keuangan, Jakarta: PT. Rineka Cipta.

Albahi. M. (2015). Analisis Rasio Likuiditas, Rasio Rentabilitas, Rasio Solvabilitas Pada Kinerja Keuangan Pt. Bank Sumut Cabang Pimbagi Medan. Jurnal Ilmiah "DUNIA ILMU” Vol.1 No.2 April 2015 Melalui : < content/uploads/2016/03/Analisa-Rasio-Likuiditas-Rasio-Rentabilitas-RasioSolvabilitas-Pada-Kinerja-Keuangan-Pt.-Bank.Pdf $>$

Amanah, R.,Atmanto, D., Aziza, DF. (2014). Pengarub Rasio Likuiditas Dan Rasio Profitabilitas Terbadap Harga SAHAM (Studi pada Perusahaan Indeks LQ45 Periode 2008-2012) Melalui $<\underline{\text { https://media.neliti.com/media /publications/83167-ID-pengaruh-rasio-likuiditas- }}$ dan-rasio-prof.pdf>.

Arthur J. Keown, David F. Scott, Jr., John D. Martin, J. William Petty. (2011). Manajemen Keuangan : Prinsip dan Penerapan : Edisi Kesepuluh Jilid 1. Indeks Penerbit.

Arif, NRA. (2012). Lembaga Keuangan Syariah. CV Pustaka Setia : Bandung

Astuti, D. (2004). Manajemen kenangan perusabaan. Jakarta: Ghaila Indonesia

Barus, AC. (2011). Analisis Profitabilitas Dan Likuiditas Terhadap Capital Adequacy Ratio (Car) Pada Institusi Perbankan Terbuka Di Bursa Efek Indonesia. Melalui $<$ https://media.neliti.com/media/publications/24337-ID-analisis-profitabilitas-danlikuiditas-terhadap-capital-adequacy-ratio-car-pada.pdf $>$

Djafar. S. (2008). Rasio Likuiditas, Profibilitas Dan Efisiensi Pada Koperasi Serba Usaha Bait Al-Maal Wa At Tamwil Madinah Dan Ikhwanul Mukminin Pontianak. Program Studi Ekonomi Syariah Jurusan Syariah Sekolah Tinggi Agama Islam Negeri (STAIN) Pontianak.

Fitriana, R. (2017). Efisiensi Penggunaan Modal Kerja Pada Koperasi Serba Usaha Baitul Maal Wattamwil Pontianak Tahun 2013-2015. Program Studi Ekonomi Syariah Jurusan Syariah Sekolah Tinggi Agama Islam Negeri (STAIN) Pontianak 2017.

Hardono, D.H. (2010). Analisis Pengarub Perubahan Rasio-Rasio Keuangan Bank Terhadap Perubahan Laba Perbandingan Pada Bank Asing dan Bank Domestik Periode Tahun 2004-2007, Jurnal Bisnis STRATEGI Vol. 19, No.2, Desember. Melalui: $<\underline{\text { https://ejournal.undip.ac.id/index.php/ibs/article/view/14470/11067>. Diakses }}$ Selasa 16 April 2019.

Harmono. (2009). Manajemen keuangan berbasis balanced scorecard pendekatan teori, kasus, dan riset bisnis. Jakarta : PT Bumi Aksara

Harjito, A. (2011). Manajemen Keuangan Edisi Kedua. Yogyakarta : EKONIS

Indrawati, A. (2017). Analisis Trend Kinerja Kenangan Bank Kaltim, RJABM, Volume 1, No.2, December . Melalui: $\quad<\underline{\text { http://ejurnal.untag- }}$ smd.ac.id/index.php/RJABM/article/view/3043/3014. . . Diakses: 15 April.

Ikatan Bankir Indonesi. 2016. Memahami Bisnis Bank Syariah. PT Gramedia : Jakarta 
AL-MASHRAFIYAH: Jurnal Ekonomi, Keuangan, dan Perbankan Syariah Volume 3, Nomor 1, April 2019

Jusuf, J. (2014). .Analisis kredit untuk kredit (account) officer. Jakarta : PT Gramedia Pustaka Utama

Kasmir. (2015). Analisis Laporan Keuangan. Edisi1-8. Jakarta: Rajawali Pers.

Kusdianto, D. (2007). Analisis Rasio Likuiditas Dan Profibilitas Pada Baitul Maal-Wattamwil Mujabidin Dan Aisyiyah Pontianak Program Studi Ekonomi Syariah Jurusan Syariah Sekolah Tinggi Agama Islam Negeri (STAIN) Pontianak.

Lartey, VC., Antwi1, S., \& Boadi, EB. (2013). The Relationship between Liquidity and Profitability of Listed Banks in Ghana Victor Curtis Lartey. International Journal of Business and Social Science Vol. 4 No. 3; March 2013. Melalui <f http://ijbssnet.com/journals/Vol 4 No 3 March 2013/5.pdf

Muhammad. (2007). Lembaga ekonomi Syari'ah. GRAHA ILMU : Yogyakarta

Mulyono, D. (2015). Buku Pintar Akuntansi Perbankan dan Lembaga Keuangan Syariah. Yogyakarta: ANDI.

Najmudin. (2011). Manajemen Keuangan Dan Aktualisasi Syar'iyyah Modern. CV Andi : Yogyakarta.

Peraturan Menteri Koperasi Nomor : 07/Per/Dep.6/IV/2016 Tentang Pedoman Penilaian Kesehatan Koperasi Simpan Pinjam \& Pembiayaan Syariah Koperasi

Palamai Srinivasan, P., \& Britto, J. (2017) Analysis of Financial Performance of Selected Commercial Banks in India. Melalui < https://file.scirp.org/pdf/TEL 2017121114592954.pdf>

Prasetyo, B. (2005). Metode penelitian kuantitatif. (Teori dan Aplikasi) Jakarta : PT. Raja Grafindo Persada Jakarta.

Rivai, V., Modding, B., Veithzal, AP., \& Mariyanti, T. (2013). Financial Institution Management (Manajemen Lembaga Keuangan) Jakarta : PT Raja Grafindo Persada. Jakarta.

Sirait, P. (2014). Pelaporan dan laporan keuangan. Graha ilmu : Yogyakarta

Suhendi, H. (2004). BMT \& Bank Islam Instrumen Lembaga Keuangan Syariah. Bandung: Pustaka Bani Quraisy.

Sulindawati, NLGE., Yuniarta, GA., \& Purnamawati, IGA. (2017). Manajemen Kenangan Sebagai Dasar Pengambilan Keputusan Bisnis. Depok: PT Raja Grafindo Persada

Suryani. (2011), Analisis Pengaruh Financing To Deposit Ratio (FDR) Terhadap Profitabilitas Perbankan Syariah Di Indonesia, Skripsi. STAIN Malikussaleh Lhokseumawe.

Supranto, J. (2008). Statistik Teori dan Aplikasi . Penerbit Erlangga : Jakarta

Subana, H.M. (2005). Dasar-Dasar Penelitian Ilmiah. Bandung : CV Pustaka Setia

Soemitra, A. (2009). Bank \& Lembaga Keuangan Syariah Jakarta : Kencana

Soeparno. (2017). Dana Nasabah Rp6,8 Miliar Tertahan di BMT Sabilillah Slogohimo. Melalui $<$ http://www.harianjogja.com/baca/2017/02/28/perbankan-wonogiri-dana-nasabahrp68-miliar-tertahan-di-bmt-sabilillah-slogohimo-797321> Diakses pada Selasa, 28 Februari 2017 22:15 WIB. 
Muhammad Syaifullah, et al. Metode Kuadrat Terkecil Untuk Meramalkan...

Tugas, FC. (2012). A Comparative Analysis of the Financial Ratios of Listed Firms Belonging to the Education Subsector in the Philippines for the Years 2009-2011. Melalui < http://ijbssnet.com/journals/Vol 3 No 21 November 2012/19.pdf>.

Theogene.,H., Mulegi, T., Hosee, N. (2017). The Contribution Of Financial Ratios Analysis On Effective Decision Making In Commercial Bank International Journal of Management and Applied Science, ISSN: 2394-7926 Volume-3, Issue-6, Jun.-2017. Melalui < http://www.iraj.in/journal/journal file/journal pdf/14-381-150400875033$\underline{40 . p d f}>$

Tampubolon, L. (2015). Analisis Pengaruh Rasio Keuangan: Likuiditas, Aktivitas Dan Leverage Terhadap Penilaian Kinerja Kenangan Studi Empiris: Perusahaan Manufaktur Di Bursa Efek Indonesia Periode 2010 - 2012. Melalui file:///C:/Users/user/Downlods /11-18-1$\underline{\mathrm{SM} \% 20(2) . p d f}$ 